\title{
The Effectiveness of the Technique of Counseling with a Lecture about the Protocols of Health Knowledge, Attitude and Behavior of the Community in the Pandemic of Covid-19 in Puskesmas Sei Suka
}

\author{
Melysa $^{\mathbf{1}}$, Chrismis Novalinda Ginting ${ }^{2}$, Sri Wahyuni Nasution ${ }^{\mathbf{3}}$, Ermi Girsang ${ }^{\mathbf{4}}$ \\ ${ }^{\text {I}}$ Postgraduate Students Department Magister of Public Health, Faculty of Medicines at University Prima \\ Indonesia \\ ${ }^{2,3,4}$ Postgraduate Lecturer Department Magister of Public Health, Faculty of Medicines at University Prima \\ Indonesia
}

\begin{abstract}
Corona Virus Disease 19 or better known as the corona virus or Covid-19 is an emergency global health. To reduce and prevent transmission of this virus, the government has required people to keep the protocol health but people still do not comply. This study aims to determine the effectiveness of the technique of counseling with a lecture about the protocols of health knowledge, attitude and behavior of the community. The type of this research is experimental (experimental), namely quasi-experimental (quasi-experimental) design with pretest and posttest. The sample in this research is that people in the working area of Puskesmas Sei Suka as many as 100 people. Data were analyzed using Paired Ttest. The results of the research that there is influence between the extension teaching methods of the protocols of health knowledge $(p=0,021)$, attitude $(p=0.008)$ and behavior $(p=0.016)$. It is recommended to the relevant government agencies in the District of Coal to be intense counseling to the community, especially about the protocol health a daily habit; do the inspection if the condition of the body is not healthy.
\end{abstract}

Keywords: counseling; knowledge; attitude; behavior; covid-19

\section{Introduction}

Corona Virus Disease 19 or better known as the corona virus or Covid-19 is an emergency global health. Corona Virus has infected more than 210 countries (Nurul Hall, 2020). Starting from one of the food market in Wuhan, China, which reported the presence of 27 people suffering from a disease similar to pneumonia, fever, difficulty breathable and the lungs are not normal. China reported the case to the WHO (World Health Organization) on January 5, 2020 that there were 41 cases and one of them died. In Indonesia the case of the first times confirmed that on March 2, 2020, where there were only 2 patients and continue to be an increase (Usman, Budi and Nur Adkhana Sari, 2020) until on 10 April 2020 in Indonesia was reported as 3.512 the case of a positive, 282 people recover and 306 people have died with a mortality rate of $9.1 \%$ (Ilpaj and Nurwati, 2020). The Virus is known to spread from one individual to another in a short time, there are two ways spread it through droplets or splashes out of the nose or mouth and through airborne or air. As for the symptoms caused by the flu, high fever, cough, shortness of breath, fatigue and no appetite (Ratio and the Secretariat, 2019) (Utami, Mose and Martini, 2020).

In a report to the WHO on December 9, 2020 in the world as much as 67.780.361 cases of confirmed Covid-19 including 1.551.214 death and 546.703 new cases and in parts of Southeast Asia confirmed 11.195 .839 cases (WHO, 2020). Reported as much as 592.900 positive cases in Indonesia on 9 December 2020 with 487.445 people recover and 18.171 people died. According to the data BPBD Medan City there are 7.980 the case of 
confirmation of covid-19 with 326 cases died per December 9, 2020 (Pemkomedan, 2020). Research conducted by Siti Setianti, et al concluded that Covid-19 hit Indonesia, the most severe, namely, the CFR of 8.9\% at the end of March 2020 (Setiati and Anwar, 2020).

The outbreak caused by the Novel Corona virus $(\mathrm{NCoV})$ that has been designated as a global pandemic by the World Health Organization (WHO). In Indonesia, the pandemic Covid-19 has been defined as a type of disease that can cause Emergencies of Public Health on March 31, 2020, according to the Presidential Decree No. 11 of the Year 2020 on the Determination of Emergency Public Health Corona Virus Disease (Covid-19). With the absence of such determination, prevention efforts must be done in accordance with the laws and regulations in the emergency handling of Covid- 19.

To reduce and prevent transmission of this virus, the government has required people to keep the protocol health. The Task force Handling of Covid-19 continues to convey the message to the entire community to reduce the risk of transmission of the virus Covid-19, such as the silence in the house, using masks, frequent hand washing using soap and running water, keeping the physical distance (physical distancing), and not touching the face, eyes, nose, and mouth. However, the application of social behavior that is new in the community is not easy, and there are some people still have not obeyed in the application of this new habit.

A new habit in maintaining the health of this can be explained by several theories about behavior. Theory of Planned Behavior by Ajzen (2005) explained that individual behavior is driven intention is influenced by three factors: Behavioral Beliefs, Normative Beliefs, and Control Beliefs. In addition, factors such as personal factors, social, and information into the factors that affect individual behavior. Behavior to prevent disease is also described in the Protection Motivation Theory which states that health information is a warning to change the attitudes of individual behavior. The theory developed by Rogers \& Prentice-Dunn, (1997) explains that from the information obtained, the motivation to protect themselves rely on the assessment of threat (threat appraisal) and a strategy in the face of threat (coping appraisal) (Hamdani, 2020).

Bashirian, et al. (2020) has conducted a study of behavior of employees in the hospitals of Iran in the prevention of transmission of Covid-19. The result states that the perception of threat (severity) and the effectiveness of the advice that recommended giving influence the behavior of the officer/medical personnel in the prevention of transmission of this virus. In addition, the characteristics of the demographic also give the perception of threat, where the woman has a threat assessment is high. Based on these studies, Bashirian,et al.(2020) emphasize the importance of the information to improve the perception of the effectiveness of behavior is protective against Covid-19. A study conducted by Prasad et al. (2020) also shows that an understanding of Covid-19 has a significant direct influence on the perception of threat and the level of severity. Furthermore, the threat and the severity of the perceived has an effect that is significant to the intention to behave even if indirectly. Then, these intentions directly affect significantly on the behavior of a person.

Yanti,et al.(2020) also stated that the implementation of behavioral health is closely related to the knowledge and response or attitude of a person. Research that analyzes the behavior of the devout on the policy of social distancing as the prevention of transmission of Covid-9 in Indonesia shows that the level of education and job affect a positive attitude in the application of social distancing. Good knowledge in the effectiveness of social distancing and an attitude or a positive response will increase the intention to behave according to the recommendations of the government. 
Research on the behavior in the prevention of transmission of Covid-19 have been conducted by Triyanto \& Kusuma wardani (2020), which states that the minimal knowledge regarding the Covid-19 affect a person's behavior. A good knowledge about the prevention of transmission of Covid-19 will increase the level of awareness and understanding about the importance in preventing the transmission of this disease. Knowledge or information obtained is influenced by the level of education of society and the characteristics of the region (urban or rural). Research conducted in France by Raude, et al.(2020) explained that there are differences in the behavioral responses to Covid-19 contagion, where male and young age are more likely to not adhere to the advice of the government. Coronavirus is a virus that belongs to the Coronaviridae family that can infect humans and animals (Hanum, 2021). However, such behavior can still be changed to emphasize the norms of positive to promote health behaviors are adaptive. Based on the literature, the differences in the characteristics and ratings of the community determine the behavior in maintaining the health or disease transmission. The perception of the public who are not motivated to keep myself this will have an impact on the transmission of Covid-19 is widespread.

Events stated that compliance can be improved through increasing public awareness of effective communication through a variety of media and methods in accordance with the diversity of the community, the campaign is clear and focused, easy access to health care with clear information and are constantly so that people quickly perform diagnostic procedures, treatment and isolation of the self when it is infected and a consistent policy that does not confuse the public.

Act No. 36 year 2009, health counseling held to improve the knowledge, awareness, willingness, and ability of the community to live a healthy life, and actively participate in the efforts of health. Health education is an activity that is inherent in every activity health efforts. Health education was held to change the behavior of a person or group of people to live a healthy life through communication, information, and education. Health education can be done using a variety of methods. The method used depends on the target. The method that is often used in counseling is the lecture method.

The results of the research Sefrizon 2011 about the influence of lectures, group discussions towards the knowledge and skills of prevention of transmission of tuberklosis lung on elementary school students in the District of Solok that mention the influence of lectures, group discussions can provide the difference knowledge and skills of elementary school students in the prevention of transmission of tuberklosis lung. Research conducted by the Meherdika year 2014 on the extension with the lecture against the knowledge and attitude of mothers about exclusive breastfeeding in District Kanigoro Blitar Regency mention that there is the influence of counseling with the lecture method with the improvement of knowledge and attitude of mothers. Research conducted by Suraya 2011 about counseling with lectures and leaflets against the knowledge and attitude of mothers about the pattern of provision of complementary feeding in children 6-24 months in the Village Beach Gemi District Stabat Regency Langkat mention that the extension teaching methods and leaflets to increase the knowledge and attitude of mothers. (lubis) Alfianur (2017) on the impact of health education method lectures on the prevention of dengue fever on the grade 5 students explain that there is a significant influence in improving the behavior of students of class 5 before and after administration of health education lecture method without media leaflet. Lubis (2013) explains that there is the influence of counseling by the method of lectures and discussions to increase knowledge and the child's attitude about PHBS in Elementary School 065014 Village Namogajah District Medan Tuntungan 2013. 


\section{Review of Literature}

\subsection{Protocol Health}

Protocol health is an alloy or the ordinances of the activities carried out in order to guarantee the individual and the community in order to remain healthy shielded from certain diseases. The purpose of the application protocol health is to improve the prevention and control of the disease Covid-19 in places and public facilities in order prevention epicenters/new clusters during the pandemic. (Arifin, 2020).

\subsection{Knowledge, Attitudes, and Behavior}

Knowledge is the result of human sensing, or the result of know somebody against an object through the senses he had so as to produce knowledge. Sensing occurs through the five human senses, namely, the senses of hearing, sight, smell, feeling, and sensing. Most of human knowledge is obtained through the eyes and ears (Usman, Budi and Nur Adkhana Sari, 2020).

Attitude is the evaluation or reaction to the feeling. A person's attitude toward an object is a feeling of support or siding and feelings does not support or is not impartial on the object. The structure of an attitude consists of three components that support each other the formation of a person's attitude in everyday life, namely the cognitive component (perceptions, beliefs, and stereotypes), affective component (feelings or emotions), and conative component (the tendency to act or behave). Also, there are several factors which can affect the nature of that personal experience, emotional factors, the influence of people who are considered important, culture, mass media, institutions of education and religious institutions (Usman, Budi and Nur Adkhana Sari, 2020).

The behavior is all the activities or the activities of mankind have a very wide scope, such as talking, walking, crying, laughing, writing, reading, and so on that can be observed or not observable by outside parties (Notoatmodjo, 2014).

\subsection{Covid-19}

Corona viruses are large family of viruses that cause illness ranging from mild symptoms to severe and is a zoonotic disease (transmitted between humans and animals). In humans usually cause disease respiratory tract infections, started common cold to serious diseases such as Middle East Respiratory Syndrome (MERS) and Acute Respiratory Syndrome Severe/ Severe Acute Respiratory Syndrome (SARS). Corona virus a new kind found on humans since the extraordinary events emerging in Wuhan China, in December 2019, later named Severe Acute Respiratory Syndrome Corona virus 2 (SARSCOV2), and cause disease Corona virus Disease-2019 (Covid-19) (Moh, 2020).

\subsection{Lecture Method}

The lecture method is a teaching method that is most popular in Indonesia and abroad. The lecture method is a teaching method where the speaker conveys information and knowledge verbally to the audience who followed passively (Hisyam Zaini, Bermawy Muthe, 2008).

\section{Research Methods}

This study is an experiment (experimental), namely quasi experimental (quasiexperimental) design with pretest and posttest. This study aims to determine the effectiveness of the technique of counseling with a lecture about the protocols of health 
knowledge, attitude and behavior of the community in the pandemic Covid-19 in Puskesmas Sei Suka. This study was conducted in Puskesmas Sei Suka. This study was conducted starts January beginning of workmanship of the proposal, implementation of the research, collection and management of data to reporting the results of the study.

The population in this research is all the head of the family's work in the region of Puskesmas Sei Suka as much as 7.316 people. Sample Research Large minimum sample required is determined by the formula Lameshow so that the number of samples in this study as many as 73 people the head of the family. The sampling technique used is purposive sampling, namely the technique of determining the sample with a certain consideration.

The type of Data used in this research is primary data and secondary data. Secondary Data is data obtained from the results of the questionnaire and the primary Data covering the descriptive number of patients with covid-19 in the Village of Tanjung Tiram.

\section{Discussion}

\subsection{The Average Value of Public Knowledge about the Protocol's Health before and after Counseling with Lecture Method in Puskesmas Sei Suka}

Knowledge is the result of the know, and this happens after someone is doing the sensing of a particular object. Sensing occurs through the five human senses, namely the senses of sight, hearing, smell, taste, and conjecture. A large part of human knowledge acquired through the eyes and ears. Knowledge or cognitive is dominant which is very important in shaping a person's actions (Notoadmojdo, 2014)

The results of the research showed that public knowledge about the protocol of health before done counseling with the lecture method obtained an average value 6,81 with a standard deviation of 1,143 . Knowledge as the basis for a person to behave. People who have a good understanding of protocol health prevention of Covid-19, then it will be a reference for him to attempt to prevent the transmission of the disease, as already understand the dangers as well as transmission of the disease Covid-19. Knowledge also influence how the community in maintaining the durability of the body.

In this study, many people who are not adherent to the protocol health. People do not know about Covid-19 and there are also people who do not believe in the disease. It is necessary to increase the knowledge of the community through health education.

Extension teaching methods can improve the knowledge. This agrees with the approach of Green in Tampubolon (2016) that with the approach of addition can change the behavior of a person, including knowledge, where the intervention is the process of health education for behavior change. Taking a Green approach in line with the research Pulungan (2017) which prove that the method of health education with lectures can increase the knowledge of having done the post-test compared to pre-test.

After extension of the health of the obtained results of the research that the public's knowledge about the protocol health after counseling with the lecture method obtained an average value of 10.04 with the standard deviation of 2,136. Changes in community knowledge about the protocol health. The material in the lectures delivered by using language that is easily understood by the respondents. The advantages of the lecture method and the language delivered by way of easy to understand as well as the presence of two-way communication between the extension of health and the question of the respondents make the respondents more understanding of the material presented by the instructor. According to Henry and the Goddess (2018) factors affecting the level of knowledge of a person derived from the information it receives, with a source of 
information that is a lot of one of them comes from health care workers will increase more and more knowledge.

The results of this study in line as proposed by WHO in Notoatmodjo (2014), one is to change behavior is the provision of information in order to improve the knowledge thus arises the awareness that in the end people will behave in accordance with their knowledge of such. One of the efforts to provide information that can be done is counseling. Knowledge occurs after someone is doing the sensing of an object or stimulus. With Notoatmodjo (2014) also eat more vegetables that attitude change is essentially influenced by the factors of knowledge and belief/ trust obtained from the results of sensing, one of which is obtained through education or learning process.

\subsection{The Average Value of the Attitude of the Public about the Protocols of Health before Done Counseling with Lecture Method in Puskesmas Sei Suka}

Attitude is the reaction or response of someone who is still closed against a stimulus or a particular object, which already involves the factors of the opinions and emotions are concerned (happy not happy, agree not to agree, not good). The results of the research showed that the attitude of the public about the protocols of health before done counseling with the lecture method obtained an average value of 27,96 with a standard deviation of 4,408. Before counseling visible to the community does not comply with the protocol of the health of not bring the mask from his home and not wear a mask properly. The problem is seen when the question and answer session before counseling begins. A society that does not bring the mask from his home less understand the importance of the benefits and objectives of the importance of following the protocol of health.

After education and re-open the question and answer session, the changes are very clearly visible. The results of the research showed that the attitude of the public about the protocols of health after counseling with the lecture method obtained an average value of 43,38 with a standard deviation of 4,320 .

The results of this study prove that the method of the talk show the results more effective in improving knowledge and attitude of the public about the protocols of health. It is seen from the average value of the knowledge and attitudes that is. This is because on lecture method all participants were actively involved to express their opinions and experiences, as well as discuss the material Covid-19 a share to acquire the appropriate conclusion. The principle of learning by way of connect-connect or association of the stimulus with the experience or the old behavior then the message will be more easily accepted and understood (Setiana, 2015).

This research is in line with research conducted by Tarigan (2016) in his thesis about the effectiveness of the method of group discussion and lectures on knowledge and attitude about reproductive health in adolescents in the Education Foundation of Hope Bloom Terrain mention that the lecture method group more effectively provide results that are more effective in improving knowledge and attitude of students about adolescent reproductive health. And this study is also in line with research conducted by Nurhayati (2016), which explains that the lecture method group can increase the knowledge of the attitude of youth in a more effective in improving knowledge and attitude of the child about PHBS. It is seen from the average value of the knowledge and attitudes was higher in the group with the lecture method is compared with the average value of knowledge and attitudes in the group with the discussion method.

This is because on lecture method all participants were actively involved to express their opinions and experiences, as well as discuss the material Covid-19 a share to acquire the appropriate conclusion. The principle of learning by way of connect-connect or 
association of the stimulus with the experience or the old behavior then the message will be more easily accepted and understood (Setiana, 2020).

\subsection{The Value of the Average Behavior of the Community about the Protocols of Health before Done Counseling with Lecture Method in Puskesmas Sei Suka}

Behavioral health of the community is a reflection of the level of public awareness is still very low. Various factors why people do not heed the protocol of health Covid-19. The behavior which is the unity of the system of knowledge that is owned by the community and how to respond to the phenomenon that occurs when the pandemic Covid19 through the concrete actions they make. The results of the research showed that the behavior of the community about the protocol of health before done counseling with the lecture method obtained an average value 6,58 with a standard deviation of 1,208.

After health education with lecture method then changes and can be seen from the research results obtained that the behavior of the public about the protocol health after counseling with the lecture method obtained an average value of 9,19 with a standard deviation of 1,916. Media discourse can have an impact on the improvement of the understanding and behavior change (Mulyani, 2020). The factors that affect the success of the counseling namely individual factors, the presentation of the material, the selection of words used, the visualization in the media as well as the audio used in the video media. Individual factors is that of the characteristics of the nature of the individual in understanding a material leaflet or video, the capacity of understanding people's certainly different and the tendency of interest in a given material is also different, some are more like the material presented in the form of text, nothing needs to be added visualization of the image there are even more fond of the visualization of the image and the audio. Material and choice of words affects the success of the counseling because if the material and the selection of the words used are too complicated will complicate the public in understanding the material presented, in addition visualization and audio greatly affect the interest in seeing or reading media socialization, visualization and audio that does not comply will cause people to be bored so that it will not achieve the outcomes of the socialization expected.

4.4 The Effectiveness of the Technique of Counseling with a Lecture about the Protocols of Health Knowledge, Attitude and Behavior of the Community in the Pandemic of Covid-19 in Puskesmas Sei Suka

The results of the research showed that the average value of the knowledge before counseling with the lecture method 6,81 with a standard deviation of 1,143 and after counseling with the lecture method occurs an increase of 10.04 with the standard deviation of 2,136, with a mean difference of $-3,230$ which means that the average public knowledge increased $t$ by 3,230 after being given counseling with the lecture method. It can be concluded that there is influence of extension teaching methods against public knowledge about the protocol health with a value of $\mathrm{p}=0,021$.

\section{Conclusion}

1. The average value of the knowledge, attitude and behavior of the community about the protocols of health before done counseling with the lecture method that is 6,81 with a standard deviation of 1,143 , the average value of the attitude that 27,96 with a standard deviation of 4,408 , the average value of the behavior that is 6,58 with a standard deviation of 1,208 . 
2. The average value of the knowledge, attitude and behavior of the community about the protocol health after counseling with the lecture method, namely of 10.04 with the standard deviation of 2,136, the average value of the attitude that 43,38 with a standard deviation of 4,320 , the average value of the behavior that is 9,19 with a standard deviation of 1,916 .

3. The technique of counseling with a lecture about the protocols of the health effect on knowledge $(\mathrm{p}=0,021)$, attitude $(\mathrm{p}=0.008)$ and behavior $(\mathrm{p}=0.016)$.

\section{References}

Arifin, P. D.dr. S. (2020). Pentingnya Penerapan Protokol Kesehatan dalam Rangka Menurunkan Transmisi Covid-19. Availableat:https://covid19.ulm.ac.id/pentingnyapenerapan-protokol-kesehatan-dalam-rangka-menurunkan-transmisi-covid-19/.

CDC. (2020). Virus corona Disease 2019 (COVID-19). Centers for DiseaseControl and Prevention.' Available at: https://www.cdc.gov/virus corona/2019-ncov/prepare/.

Farokhah, L., Ubaidillah,Y.and Yulianti, R.A. (2020). Penyuluhan Disiplin Protokol Kesehatan Covid-19 Di Kelurahan Gandul Kecamatan Cinere Kota Depok', Seminar Nasional Pengabdian Masyarakat LPPMUMJ,pp.1-8.

Hanum, P.S., Darmawan, N.M.E.P., and Hasmono, D. (2021). Practical Analysis Antibiotics Use for Covid 19 Patients. Budapest International Research in Exact Sciences (BirEx) Journal Vol 3 (4): 274-290.

Herniwanti, H. etal. (2020). Penyuluhan Perilaku Hidup Sehat Dan Bersih (PHBS) dan Gerakan Masyarakat Hidup Sehat (GERMAS) kepada Lanjut Usia (LANSIA) Menghadapi Masa P Covid 19 dan New Normal dengan Metode 3M', Jurnal Abdidas,1(5),pp.363-372.doi: 10.31004/abdidas.v1i5.82.

Hisyam Zaini, Bermawy Muthe, S. A. (2008). Strategi Pembelajaran Aktif. yogyakarta: permata insan madani.

Ilpaj, S.M. and Nurwati,N. (2020). Analisis Pengaruh Tingkat Kematian Akibat Covid-19 Terhadap Kesehatan Mental Masyarakat Di Indonesia', Focus : Jurnal Pekerjaan Sosial,3(1),p.16.doi:10.24198/focus.v3i1.28123.

Kemkes (2020). Kesiapan Kemenkes Dalam Menghadapi Outbreak Novel Corona Virus (2019-nCoV)'.

Majid, A. (2009). Perencanaan Pembelajaran.Bandung: PT. Remaja Rosda Karya.

Mawuntu, A. H. P. etal. (2018). Evaluasi Efektifitas Prosedur Cuci Tangan pada Operator Fungsi lumbal Di Bagian Neurologi RSUP R.D. Kandou Manado. Jurnal Sinaps,1(1),pp.47-

66.Availableat:http://jurnalsinaps.com/index.php/sinaps/article/download/16/8.

Notoatmodjo, S.(2014). Ilmu Perilaku Kesehatan. Jakarta: Rineka Cipta.

Nurul Aula, S. K. (2020). Peran Tokoh Agama Dalam Memutus Rantai Pandemi Covid-19 Di Media Online Indonesia. Living Islam: Journal of Islamic Discourses, 3(1),p.125.doi:10.14421/lijid.v3i1.2224.

Papdi. (2020). Pedoman tata laksana covid-19 edisi 3. Availableat:https://www.papdi.or.id/download/983-pedoman-tatalaksana-covid-19edisi-3- desember-2020.

Pemkomedan. (2020). Data General Terkait Covid-19 Kota Medan'.Availableat:https://covid19.pemkomedan.go.id/index.php?page=stat_medan.

Purnamasari, I. and Raharyani, A. E. (2020). Jurnal Ilmiah Kesehatan 2020, 19(Mei),pp.33-42.

Ratio, W. and Secretariat, A. (2019). Metrik Serial Teknologi Dansains. Vol.1 No.1 
http://publikasi.kocenin.com/index.php/teksi', 1(1), pp. 8-14.

Setiati,S.and Azwar,M.K.(2020). Covid-19 and Indonesia',52(1),pp.84-89.

Usman, S., Budi, S. and Nur Adkhana Sari, D. (2020). Pengetahuan Dan Sikap Mahasiswa Kesehatan Tentang Pencegahan Covid-19 Di Indonesia. Jurnal Ilmu Keperawatan dan Kebidanan, 11(2), pp. 410-414. Available at: Pengetahuan Dan Sikap Mahasiswa Kesehatan Tentang Pencegahan Covid-19 Di Indonesia.

Utami, R. A., Mose, R. E. and Martini, M. (2020). Pengetahuan, Sikap dan Keterampilan Masyarakat dalam Pencegahan Covid-19 di DKI Jakarta. Jurnal Kesehatan Holistic,4(2),pp.68-77.doi:10.33377/jkh.v4i2.85.

WHO. (2020). WHO Coronavirus Disease (Covid-19) Dashboard. Available at:https://covid19.who.int/info.

Wu C, Chen X, Cai Y, Xia J, Zhou X, Xu S,et al. (2020) 'Risk Factors Associated With Acute Respiratory Distress Syndrome and Deathin Patients With Virus corona Disease 2019 Pneumoniain Wuhan, China.', JAMA Intern Med. Available at: https://www.ncbi.nlm.nih.gov/pmc/articles/PMC7070509/. 